\title{
Ectoparasites (Polyctenidae, Streblidae, Nycteribiidae) of bats (Mammalia: Chiroptera) from the Caribbean region of Colombia
}

\author{
Berta Calonge-Camargo ${ }^{1}$ and Jairo Pérez-Torres ${ }^{1 *}$ \\ 'Laboratorio de Ecología Funcional, Unidad de Ecología y Sistemática (UNESIS), Departamento de Biología, Facultad de Ciencias, \\ Pontificia Universidad Javeriana. Carrera 7 \# 43-82, Ed. 53, Of. 406B, Bogotá, D.C., Colombia. Email: bertica@gmail.com (BHC), \\ jaiperez@javeriana.edu.co (JPT). \\ * Corresponding author
}

\begin{abstract}
Bats are hosts of a high taxonomic diversity of ectoparasites. Six hundred eighty seven insect species have been reported as bat ectoparasites, belonging to orders Dermaptera, Lepidoptera, Diptera and Siphonaptera (Marshall 1982). This study lists an inventory of bat ectoparasites found in fragments of Tropical Dry Forest on the Caribbean coast of Colombia. The study was conducted in the Department of Cordoba in four farms with fragments of Tropical Dry Forest. Bats were captured using mist nets and were collected and stored in plastic bags for subsequent examination in the laboratory. Ectoparasites were stored in alcohol and identified using a stereomicroscope and taxonomic keys. Two hundred fifty one bats belonging to 21 species were captured. The most abundant family was Phyllostomidae, followed by Emballonuridae, Noctilionidae, Vespertilionidae and Molossidae. Twelve genera of ectoparasites were found, belonging to families Streblidae, Nycteribiidae and Polyctenidae. Streblidae was the most abundant family and included the largest number of species. Thirty five percent of bats examined were hosts to at least one ectoparasite species. In this study, carried out in fragments of tropical dry forest in Cordoba, Colombia, we recorded dipterans in 17 out of 21 bat species. Hemypteran ectoparasites of the family Polyctenidae were found in Molossus molossus only. Eighty seven individual dipterans were found among 51 Carollia perspicillata specimens, which is consistent with the high parasitism levels previously reported. The bat species C. brevicauda, P. discolor, U. bilobatum and C. perspicillata carried the highest number of ectoparasite species.
\end{abstract}

Los murciélagos son hospederos de numerosas especies de ectoparásitos pertenecientes a diversos grupos taxonómicos. Se conocen 687 especies de insectos ectoparásitos de murciélagos pertenecientes a los órdenes Dermaptera, Hemiptera, Diptera y Siphonaptera. El objetivo de esta investigación fue realizar un inventario de los ectoparásitos de murciélagos presentes en fragmentos de Bosque Seco Tropical (BST) en la costa Caribe Colombiana (Córdoba, Colombia). El estudio se realizó en el departamento de Córdoba en cuatro fincas con fragmentos de BST. Los murciélagos fueron capturados utilizando redes de niebla, y posteriormente colectados y almacenados en bolsas de plástico para su posterior revisión en el laboratorio; los ectoparásitos fueron almacenados en alcohol e identificados utilizando un microscopio estereoscópico y claves taxonómicas. Se capturaron 251 murciélagos, distribuidos en 21 especies. La familia más abundante fue Phyllostomidae, seguida de las familias Emballonuridae, Noctilionidae, Vespertilionidae y Molossidae. Se encontraron 12 géneros de ectoparásitos, distribuidos en las familias Streblidae, Nycteribiidae y Polyctenidae. La familia Streblidae fue la más abundante y presentó la mayor riqueza de especies. El $35 \%$ de los murciélagos estudiados presentaron al menos un ectoparásito. En la presente investigación se encontró que de 21 especies, 17 presentaban dípteros. La especie Molossus molossus fue la única encontrada con ectoparásitos hemípteros de la familia Polyctenidae. En 51 individuos revisados de Carollia perspicillata se encontraron 87 dípteros, lo que coincide con los altos valores de parasitismo por moscas previamente reportados para esta especie. Las especies C. brevicauda, P. discolor, U. bilobatum y C. perspicillata presentaron el mayor número de especies de ectoparásitos asociados.

Key words: Caribbean region; Colombia; Cordoba; ectoparasitism; extensive livestock; Phyllostomidae; silvopastoral system; tropical dry forest. (c) 2018 Asociación Mexicana de Mastozoología, www.mastozoologiamexicana.org

\section{Introduction}

Parasites play a key role in the life of the host and often exert a significant selection pressure on them (Hart 1990; Zhang et al. 2010). By restraining resource investment in their host, parasites may affect its growth, survival or reproduction (Hart 1990; Mooring et al. 2002; ter Hofstede and Fenton 2005; Zhang et al. 2010).

The knowledge about external parasites (ectoparasites) of bats provides key information for understanding the biology, systematics and phylogeny of the host (Fritz 1983). In addition, this allows clarifying epidemiological aspects of the transmission of some diseases among bats and is essential for gaining a deeper insight on the ecology and behavior of bats in their shelters (Aguiar et al. 2006; Aguiar and Antonini 2011). A total of 687 bat ectoparasite insect species are known for bats, belonging to orders Der- maptera, Lepidoptera, Diptera, and Siphonaptera (Marshall 1982; Schuh and Slater 1995). Six families of these orders are unique to bats (Berlota et al. 2005), of which Nycteribiidae, Streblidae and Polyctenidae are those most studied and best known worldwide.

The family Nycteribiidae, which contains approximately 275 species distributed in 12 genera, includes ectoparasites that are exclusive of bats. These are highly-specialized obligated blood-feeding true flies that are wingless and show a spider-like appearance; their legs and small head protrude above the thoracic dorsal surface (Theodor 1967; Whitaker et al. 2009). This family is divided into three subfamilies: Archinycteribiinae (1 genus, 3 species); Cyclopodiinae (4 genera, 2 species), which are unique to the eastern hemisphere and are associated with bats of the taxa Pteropodidae; and Nycteribiinae (7 genera, 191 species), which are 
cosmopolitan. The family Streblidae is distributed worldwide and includes five subfamilies, 32 genera and 227 species described. The majority of streblid flies have wings, but in some genera these are vestigial, while some fully winged forms are poor flyers. Streblids are cosmopolitan flies with a well-established specificity for a host, and the largest number of species thrive in the western hemisphere (Kunz 1976; ter Hofstede et al. 2004; Dick and Gettinger 2005; Whitaker et al. 2009).

The family Polyctenidae includes bat bugs. These are rarely collected permanent ectoparasites of bats in tropical and subtropical regions around the world (Maa 1964; Marshall 1991; Esberard et al. 2005). Little is known about the taxonomy of this family, in which 32 species in five genera have been described (Maa 1964; Marshall 1991). The genus Hesperoctenes (16 species) is restricted to the western hemisphere, while the four remaining genera are unique to the Old World, which is apparently the center of origin of this group (Ueshima 1972; Esberard et al. 2005). Polyctenid bugs are exclusive parasites of microchiropterans, feeding on their blood (Maa 1964; Ueshima 1972; Marshall 1991), and are highly host-specific (Ryckman and Casdin 1977; Whitaker et al. 2009).

In Colombia, between the decades of 1940 and 1970, some descriptions and inventories of parasite species and their hosts were carried out (Boshell and Kerr 1942; Marinkelle 1967; Clark 1967; Machado-Allison and Antequera 1969; Marinkelle and Grose 1981). Tasmitt and Fox (1970) elaborated a list of ectoparasites of bats for Colombia and Puerto Rico, recording 28 species parasitizing 18 bat species for Colombia. The study of ectoparasites of bats in the country was subsequently abandoned. In 2012, CalongeCamargo evaluated the ectoparasites of bats in fragments of tropical dry forest subjected to conventional livestock and silvopastoral management in the Department of Córdoba, and observed changes in the species composition of ectoparasites and their degree of specificity. HerreraSepúlveda (2013) compared the ectoparasite load in harems and mixed groups of a Carollia perspicillata population in Cueva Macaregua (Santander), finding higher diversity and richness of ectoparasites in harems versus mixed groups. Tarquino-Carbonell et al. (2015) elaborated an inventory of ectoparasites of bats in a gallery forest in Vereda El Chorrillo (Tolima), and reported 24 species of ectoparasites associated with 14 bat species. Dick et al. (2016) developed a catalog of parasites of the family Streblidae in Colombia, including 73 species distributed in 19 genera and 3 subfamilies. Duran et al. (2017) recorded 17 species belonging to 8 genera of Streblidae that parasitize 19 bat species of five families in the Department of Sucre. Despite the recent interest in the study of bat ectoparasites in Colombia, no studies are currently available for environments subjected to extensive livestock farming in the Caribbean zone of Colombia. This paper lists the ectoparasites of bats found in fragments of tropical dry forest (BST) in the Caribbean region of Colombia (Cordoba, Colombia).

\section{Materials and Methods}

Study area. Sampling was conducted in four BST fragments located in the Department of Cordoba, northern Colombia, between $9^{\circ} 26^{\prime} 16^{\prime \prime}-7^{\circ} 22^{\prime} 05^{\prime \prime} \mathrm{N}$ and $74^{\circ} 47^{\prime} 43^{\prime \prime}-76^{\circ} 30^{\prime} 01^{\prime \prime}$ W. The main vegetation types are tropical dry forest (BST) in the low zone, and tropical moist forest (BHT) in higher elevations (Racero-Casarrubia et al. 2015). The climate is tropical warm humid, with mean temperature of $28^{\circ} \mathrm{C}$ and mean annual precipitation of $1200 \mathrm{~mm}$ with unimodal distribution, showing a dry season from December to March, and a rainy season from April to November (Racero-Casarrubia et al. 2017). Two of the fragments were located in extensive livestock farms subjected to silvopastoral management (tree planting for timber production; Las Palmeras: fragment area $\sim 45$ ha, and San Lorenzo: fragment area $\sim 90 \mathrm{ha}$ ), and two in extensive livestock farms subjected to conventional management (pastures with scarce shrub or tree cover; Guacamayas: fragment area $\sim 34$ ha, and Chimborazo: fragment area $\sim 55$ ha; Figure 1).

Collection of Bats and Ectoparasites. Sampling was carried out from August 2011 to January 2012. Bats were captured using 14 mist nets. Ten nets were placed inside of each fragment; in order to broaden the sampling coverage in each production system, four nets were placed in the matrix adjacent to each fragment, at a distance of 20 meters maximum. For three consecutive nights, nets were opened from 6:00 p.m. to 6:00 a.m., reviewed at half-hour intervals, and relocated occasionally within the forest frag-

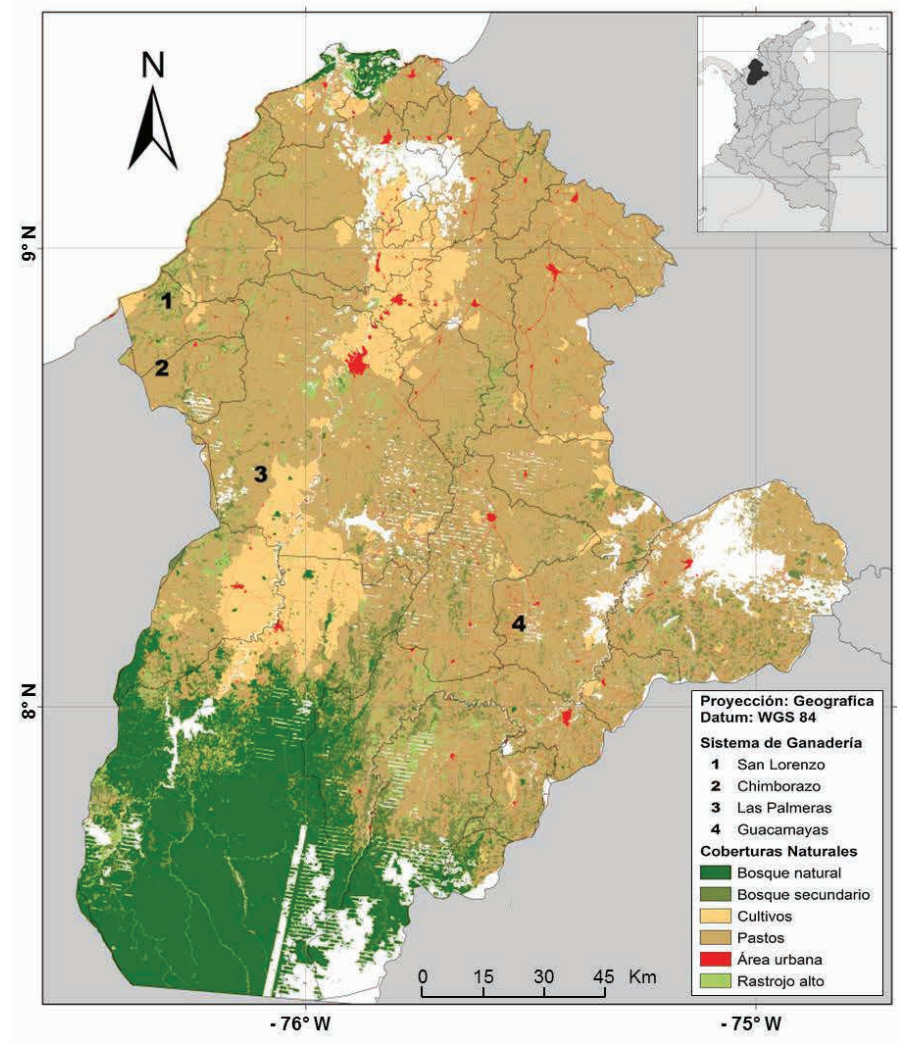

Figure 1. Map of natural cover and localities in the study area: San Lorenzo (Los Córdobas), Chimborazo (Canalete), Las Palmeras (Montería) and Guacamayas (Buenavista), in the Department of Córdoba, Colombia (modified from Ballesteros-Correa, 2015). 
ment. Seven field trips were conducted to each farm, for a total of 21 sampling nights/farm. Cumulative species curves were drawn and fitted to the Clench model to obtain an estimate of the expected number of bat and ectoparasite species (Figure 2), taking the number of specimens collected as a unit of effort (Figure 3).

Bats were killed directly on the mist net by craniocervical dislocation using forceps (Sikes 2016), and were deposited in double plastic bags, avoiding direct contact to minimize the loss of ectoparasites (Whitaker et al. 2009). Subsequently, bats were injected with $70 \%$ alcohol (through the bag) in the abdomen to prevent decomposition. The preserved specimens were transported to the Laboratory of Functional Ecology at Pontificia Universidad Javeriana, where each individual specimen was examined under a Krüss stereomicroscope (240V AC 12V/20W) To this end, specimens were placed on a white sheet and examined using fine tweezers and a dissecting needle to sort ectoparasites into separate containers. Each bat specimen was reviewed twice to maximize the detection of the ectoparasites. Ectoparasites collected were preserved in $70 \%$ alcohol (Wenzel et al. 1966; Whitaker et al. 2009). Bats and ectoparasites were deposited in the collection of mammals of the Museo Javeriano de Historia Natural (MPUJ-MAMM:1911-2162) at Pontificia Universidad Javeriana, Bogotá.

Identification of Parasites and Bats. Dipterans and hemipterans were preserved in alcohol and some were cleared with glycerin for identification. Specimens were identified using the keys of Wenzel (1976), Guerrero (1993), and Graciolli and Carvalho (2001), with the assistance of Dr. Ricardo Guerrero (Universidad Central de Venezuela; Guerrero 1997). Bats were identified using the keys of Fernández et al. (1988), Emmons and Feer (1997), Tim and LaVal (1998), Linares (1998), Laval and Rodríguez-H. (2002), and Gardner (2007).

Data Analysis. For the purposes of this work, bat parasitism patterns were evaluated at the regional level for the BST in the Colombian Caribbean, so data from the four farms were pooled together. The parasite-host association was evaluated by estimating the rates of prevalence and mean intensity (Bush et al. 1997). Prevalence was calculated as the number of bats parasitized with one or more individu-

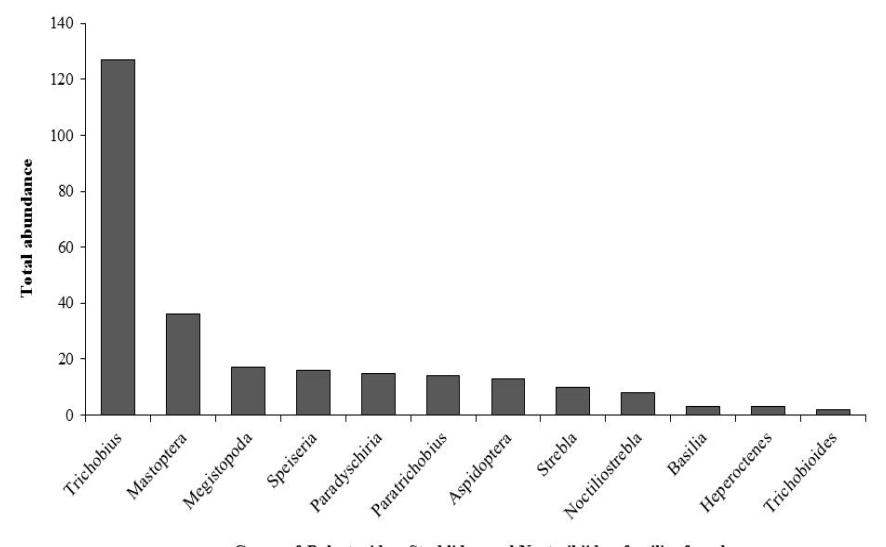

Genus of Polyctenidae, Streblidae and Nycteribiidae families found

Figure 2. Total abundance of the genera of ectoparasites found in the bats studied.

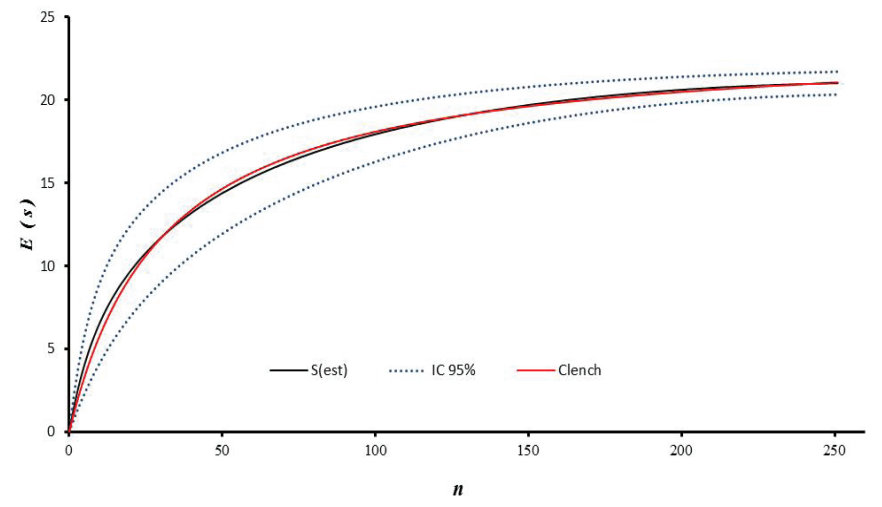

Figure 3. Species accumulation curve $S$ (est) for bats, fitted to the Clench model (red line) for species representativeness. The blue dotted line represents the $95 \%$ confidence interval. $E(S)=$ Expected Number of species. $n=$ Number of specimens.

als of a given species of parasite, divided by the number of hosts examined for that parasite species, then multiplying the resulting figure by 100 (Bush et al. 1997). Intensity was calculated as the number of parasites per bat (Christie et al. 2003), and mean intensity as the mean intensity of a parasite species relative to the total number of infected individuals of a particular bat species (Bush et al. 1997).

\section{Results}

A total of 251 bats were caught, belonging to 21 species and five families. The most abundant family was Phyllostomidae (94\% of total catch), followed by Emballonuridae (2.3\%), Noctilionidae (0.8\%), Vespertilionidae $(0.8 \%)$, and Molossidae (0.8\%). Carollia perspicillata was the most abundant species $(n=51)$, followed by Artibeus planirostris $(n=41)$, and Uroderma bilobatum ( $n$ = 35; Table 1 ). The least abundant species were mainly insectivorous bats. Correspondingly, 12 genera of ectoparasites were recorded, distributed in three families. The family Streblidae showed the highest taxonomic richness (10 genera) and the highest abundance. Trichobius was the most abundant genus (49\%), followed by Mastoptera (14\%), Megistopoda (7\%), and Speiseria (6 $\%)$ (Figure 2). The six remaining genera, i.e. Noctiliostrebla, Paradyschiria, Trichobioides, Paratrichobius Strebla, and Aspidoptera, accounted for $24 \%$ of total abundance (Table 1; Figure 2). The sampling representativeness for bats, fitted to the Clench model, was $91 \%$ (Figure 3); for ectoparasites, an $85 \%$ sampling representativeness was estimated (Figure 4).

We found three individuals each of the genera Basilia (Nycteribiidae) and Herperoctenes (Polyctenidae; Table 1). The bat species Carollia brevicauda and Phyllostomus discolor showed the largest number of associated ectoparasite species (four species each; C. brevicauda: Speiseria ambigua, Strebla guajiro, Trichobius joblingi, and Trichobius persimilis; P. discolor: Strebla hertigi, Trichobioides perspicillatum, Trichobius costalimai and Trichobius longipes), followed by U. bilobatum (Paratrichobius dunni, P. salvini and P. sp.) and C. perspicillata (Speiseria ambiguous, S. guajiro and T. joblingi), with three species each (Table 1). 


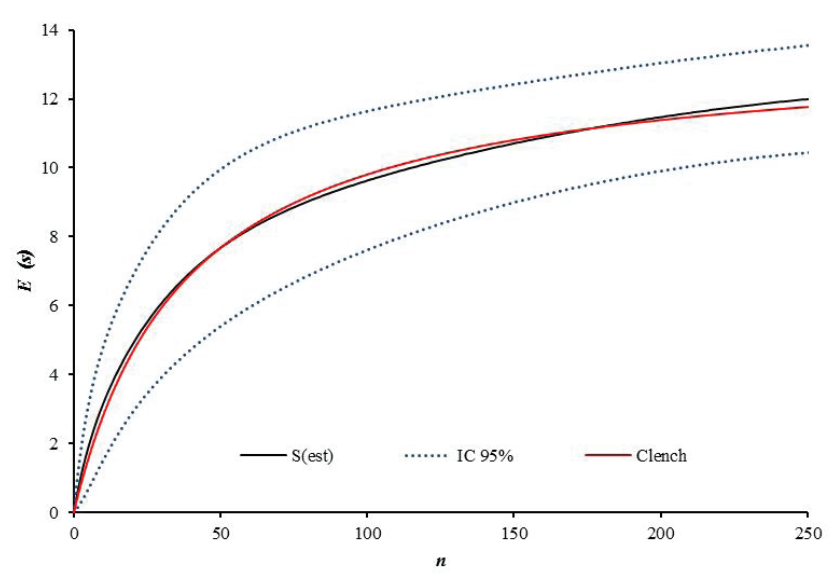

Figure 4. Cumulative curve for ectoparasites $\mathrm{S}$ (est) fitted to the Clench model (red line) for species representativeness. The blue dotted line represents the $95 \%$ confidence interval. $E(S)=$ Expected Number of species. $n=$ Number of specimens.

The total number of individuals with ectoparasites was 90 , representing a total prevalence of $36 \%$. The prevalence of the ectoparasites Noctiliostrebla maai, Paradischiria parvuloides, Mastoptera minuta, Trichobius dugesioides, Mastoptera guimaraesi, and $T$. longipes in their respective specific hosts was $100 \%$ (Table 1). In contrast, Strebla guajiro, Speiseria ambigua, Trichobius dugesii, Megistopoda aranea, Paratrichobius longicrus, and $P$. dunni showed a prevalence lower than $20 \%$ in specific hosts (Table 1).

The mean intensity of each ectoparasite species in specific hosts ranged between 0.1 and 10.5. Mastoptera guimaraesi and Trichobius longipes showed higher values, with a mean intensity of 10.5, while the genus Paratrichobius sp. showed the lowest values (Table 1).

\section{Discussion}

The bat species with the lowest ectoparasite abundance were mostly insectivorous; this finding is hardly surprising when using mist nets only, as these nets tend to be readily detected by bats and many fly above the canopy (Bergallo et al. 2003). Thirty six percent of the bats studied had at least one ectoparasite. In the Department of Tolima, Tarquino et al. (2015) found that only 8 (38\%) of the 21 bat species captured had dipterans. This study, carried out in fragments of tropical dry forest in Cordoba, found that 17 $(81 \%)$ of 21 bat species had dipterans. This difference may be due to the sample processing methods used, since dipterans tend to escape readily (Whitaker et al. 2009) when the host is manipulated. This indirect disturbance, named "transfer of disturbance" by Wenzel et al. (1966), is common among Streblidae parasites of bats captured with mist nets.

Molossus molossus was the only species found with hemipteran ectoparasites of the family Polyctenidae. It has already been reported that the members of this family of ectoparasites are unique to the family Molossidae in the Neotropics (Marshall 1982).

Eighty seven dipterans belonging to three species were found in the 51 specimens of $C$. perspicillata examined. This bat species has been reported to show high parasitism lev- els, mainly of flies (Komeno and Linhares 1999), although ter Hofstede et al. (2004) reported low ectoparasitism levels in this bat species in Belize. The high abundance of ectoparasites typically found in this species could be due to its distinctive social structure (McCracken and Wilkinson 2000). It has been reported that $C$. perspicillata usually shows a harem-type social structure (McCracken and Wilkinson 2000); it has been suggested that harems promote the exchange of ectoparasites between individuals that perch together (McCracken and Wilkinson 2000). In a separate study, Herrera-Sepulveda (2013) found in Macaregua cave (Santander, Colombia) that ectoparasitism was higher (richness and diversity) in individuals living in harems, which show a closer physical contact, relative to individuals living in mixed groups where the extent of physical contact is lower. In addition, species that tend to group together in perching sites may bear a variable number of ectoparasites, depending on the extent of allogrooming within the group (Kerth 2008; Altringham 1996). Separately, Wenzel et al. (1966) explained that the high diversity of ectoparasites in C. perspicillata results from its high ecological flexibility, that is, from the wide range of ecological conditions where it thrives.

No pattern was evident regarding the bat species showing the greatest infestation level by ectoparasites in Neotropical regions. Some studies have reported that the majority of dipteran species are associated with the genus Artibeus (Anderson and Filho 2006; Azevedo and Linardi 2002; Camilotti et al. 2010). In Brazil, Berlota et al. (2005) and Graciolli et al. (2006) reported that Sturnira lilium is the species with the highest number of etoparasite individuals and species. In Paraguay, Dick and Gettinger (2005) found that the bat species with the highest number of flies were $S$. lilium, Noctilio albiventris and Desmodus rotundus.

In this work, C. brevicauda showed the highest richness of ectoparasites, with four species. In the work carried out by Duran et al. (2017) in a tropical dry forest in Sucre, Colombia, D. rotundus and A. planirostris showed the greatest richness of ectoparasites, with seven species each. In this study, P. hastatus, N. albiventris, S. lilum, and $L$. brasiliense, respectively, followed C. perspicillata in terms of the amount of dipterans (number of individuals). The variation in ectoparasite richness per species may be due to differences in the composition and structure of the local host assemblages studied. According to Rui and Graciolli (2005), differences in ectoparasite assemblages in a given host species may also be attributed to regional differences in the species composition of bats, the biogeographic history of the area, as well as the lack of specificity of ectoparasites. On the other hand, the local environmental conditions, perching behavior of each species, as well as its social structure, may all influence these differences. The feeding habits and foraging pattern may also affect the degree of ectoparasitism, since the blood chemistry changes according to the type of food consumed by the host (Emerson and Roark 2007). 


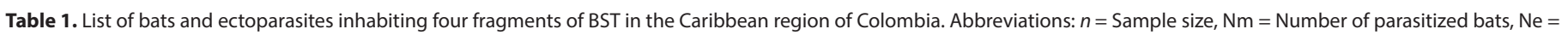
Number of bats carrying each ectoparasite species, $\mathrm{P}=$ Prevalence, $\mathrm{Mi}=$ Mean intensity.

\begin{tabular}{|c|c|c|c|c|c|c|c|}
\hline \multicolumn{4}{|c|}{ Bat } & \multicolumn{4}{|c|}{ Ectoparasite } \\
\hline Family and species & $n=251$ & $\mathrm{Nm}$ & $\mathrm{Ne}$ & Species & $\mathbf{n}$ & $\mathbf{P}(\%)$ & Mi \\
\hline \multicolumn{8}{|l|}{ Emballonuridae } \\
\hline Saccopteryx leptura & 6 & 0 & 0 & & & & \\
\hline \multicolumn{8}{|l|}{ Noctilionidae } \\
\hline \multirow[t]{2}{*}{ Noctilio albiventris } & 2 & 2 & 2 & Noctiliostrebla maai & 8 & 100 & 4.0 \\
\hline & & & 2 & Paradyschiria parvuloides & 15 & 100 & 7.5 \\
\hline \multicolumn{8}{|l|}{ Phyllostomidae } \\
\hline \multirow[t]{4}{*}{ Carollia brevicauda } & 13 & 10 & 3 & Speiseria ambigua & 5 & 23 & 0.5 \\
\hline & & & 2 & Strebla guajiro & 2 & 15 & 0.2 \\
\hline & & & 7 & Trichobius joblingi & 11 & 53 & 1.1 \\
\hline & & & 3 & Trichobius persimilis & 4 & 23 & 0.4 \\
\hline Carollia castanea & 3 & 1 & 1 & Trichobius joblingi & 1 & 33 & 1.0 \\
\hline \multirow[t]{3}{*}{ Carollia perspicillata } & 51 & 31 & 9 & Speiseria ambigua & 11 & 17 & 0.3 \\
\hline & & & 5 & Strebla guajiro & 7 & 9 & 0.2 \\
\hline & & & 28 & Trichobius joblingi & 63 & 55 & 2.0 \\
\hline Desmodus rotundus & 9 & 4 & 4 & Trichobius parasiticus & 6 & 44 & 1.5 \\
\hline Glossophaga soricina & 8 & 1 & 1 & Trichobius dugesii & 1 & 12 & 1.0 \\
\hline \multirow[t]{2}{*}{ Lophostoma brasiliense } & 3 & 3 & 3 & Mastoptera minuta & 11 & 100 & 3.6 \\
\hline & & & 2 & Trichobius silvicolae & 7 & 66 & 2.3 \\
\hline Lophostoma silvicolum & 6 & 3 & 3 & Mastoptera minuta & 4 & 50 & 1.3 \\
\hline Mimon crenulatum & 3 & 2 & 2 & Basilia sp. & 3 & 66 & 1.5 \\
\hline \multirow[t]{4}{*}{ Phyllostomus discolor } & 2 & 2 & 1 & Strebla hertigi & 1 & 50 & 0.5 \\
\hline & & & 1 & Trichobioides perspicillatum & 1 & 50 & 0.5 \\
\hline & & & 1 & Trichobius costalimai & 6 & 50 & 3.0 \\
\hline & & & 1 & Trichobius longipes & 4 & 50 & 2.0 \\
\hline Phyllostomus cf. elongatus & 1 & 1 & 1 & Trichobius dugesioides & 3 & 100 & 3.0 \\
\hline \multirow[t]{2}{*}{ Phyllostomus hastatus } & 2 & 2 & 2 & Mastoptera guimaraesi & 21 & 100 & 10.5 \\
\hline & & & 2 & Trichobius longipes & 21 & 100 & 10.5 \\
\hline Artibeus lituratus & 26 & 2 & 2 & Megistopoda aranea & 1 & 8 & 0.5 \\
\hline \multirow[t]{2}{*}{ Artibeus planirostris } & 41 & 5 & 5 & Megistopoda aranea & 6 & 12 & 1.2 \\
\hline & & & 1 & Paratrichobius longicrus & 1 & 2 & 0.2 \\
\hline Dermanura phaeotis & 6 & 0 & 0 & & & & \\
\hline Platyrrhinus helleri & 12 & 0 & 0 & & & & \\
\hline \multirow[t]{2}{*}{ Sturnira lilium } & 17 & 9 & 6 & Aspidoptera delatorrei & 13 & 35 & 1.4 \\
\hline & & & 6 & Megistopoda próxima & 10 & 35 & 1.1 \\
\hline \multirow[t]{3}{*}{ Uroderma bilobatum } & 35 & 11 & 2 & Paratrichobius dunni & 4 & 6 & 0.3 \\
\hline & & & 7 & Paratrichobius salvini & 7 & 20 & 0.6 \\
\hline & & & 2 & Paratrichobius sp. & 2 & 6 & 0.1 \\
\hline \multicolumn{8}{|l|}{ Vespertilionidae } \\
\hline Rhogeessaio & 2 & 0 & 0 & & & & \\
\hline \multicolumn{8}{|l|}{ Molossidae } \\
\hline Molossus molossus & 3 & 1 & 1 & Hesperoctenes sp. & 3 & 33 & 3.0 \\
\hline
\end{tabular}

Further studies should be conducted to analyze this relationship, since given that blood chemistry is sensitive to food type, seasonal variations in the diet may also lead to temporary changes in blood chemistry, thus leading to temporal changes in the type, extent, or prevalence of ectoparasites in bats. 
At the regional level, the richness and abundance of ectoparasite species are governed by various factors. Species richness can be explained based on the structure of vegetation, abundance of host shelters, and abundance of host species and individuals (Santos et al. 2013). Correspondingly, the abundance of ectoparasites may be related to the characteristics of the host, such as body size, sex, age, and social organization, among others (Moore and Wilson 2002, Dick et al. 2003, Morand et al. 2004, ter Hofstede and Fenton 2005, Patterson et al. 2007). The extent to which each factor determines the abundance of ectoparasites is specific to each parasite-host system (Presley and Willig 2008).

The degree of parasitism by flies per individual was found to be higher in P. hastatus. We suggest that this may be due to the size of host individuals (which in turn determines the surface area available to accommodate ectoparasites), or also to socializing in harems (potential increase in ectoparasite transfer through physical contact). These bats often use termite mounds, caves and hollow trees as perching sites (Ochoa 1985; Norman 1970). Each harem may comprise 10 to 100 females and a single male, which would facilitate the exchange of parasites among them (Santos et al. 2004). Sex ratio, as well as social structure, are factors that contribute to explain the abundance of parasites in a given species. From a work conducted in Paraguay, Presley and Willig (2008) indicated that since harems are common in the Neotropics, adult females are vectors for host-to-host infection (transferring parasites to offspring), hence skewing the infestation preference toward females vs. males.

The parasitism prevalence and mean intensity values reported in this study contrast the findings reported by Tarquino et al. (2015) also in BST fragments in the Andean Region, likely because that study captured different host species and recorded different abundance levels per species. It should also be considered that environmental conditions, the configuration of the landscape, sampling techniques, and climate season differed between our work and that of Tarquino et al. (2015). Similar to the findings of Tarquino et al. (2015), this work recorded a $100 \%$ prevalence for the association between $P$. hastatus and T. longipes, and a $50 \%$ prevalence between $C$. brevicauda and T. joblingi, although with a very small sample size $(n=2)$ in this case; therefore, sample size should be increased for these species. Separately, C. perspicillata showed a mean intensity of 2 for T. joblinji in both studies, while S. lilium had a mean intensity of 1 for Megistopoda proxima.

In conclusion, the present work recorded ectoparasites of families Streblidae, Nycteribidae, aad Polyctenidae. The bat species $C$. brevicauda, P. discolor, U. bilobatum, and $C$. perspicillata showed the largest number of associated ectoparasite species. The species of bats with the highest abundance of ectoparasites (C. perspicillata, P. hastatus, N. albiventris, $S$. lilum, and $L$. brasiliense) showed no evident overall characteristic that would explain this finding.

\section{Acknowledgments}

We would like to express our special gratitude to Dr Jesus Ballesteros-Correa (Universidad de Córdoba) for the economic and logistical support during information gathering, as well as for providing the map of the study area from his doctoral thesis. Thanks also to the owners of the Las Palmeras, Chimborazo, Guacamayas, and San Lorenzo farms for their logistical support. Sergio Solari (UA), Juan Bibiano Morales Malacara (UNAM), and Ricardo Guerrero (UCV) made valuable comments to the manuscript. Ricardo Guerrero assisted in the identification of species. Thanks to the students of Universidad de Córdoba and the Functional Ecology Laboratory for their collaboration in field work, especially to the Biologist Giselle Molina for her assistance in sample processing. The Functional Ecology Laboratory (Pontificia Universidad Javeriana) and the Laboratory of Biodiversity (Universidad de Córdoba) kindly provided logistical support. María Elena Sánchez-Salazar translated the manuscript into English. This work was part of the project: "Bats in extensive silvopastoral and conventional farming systems in the Caribbean region of Colombia" Universidad Javeriana ID \# 5688.

\section{Literature cited}

Aguiar, L., AND Y. Antonini. 2011. Descriptive ecology of bat flies (Diptera: Hippoboscoidea) associated with vampire bats (Chiroptera: Phyllostomidae) in the Cerrado of central Brazil. Memórias do Instituto Oswaldo Cruz 106:170-176.

Aguiar, L., W. Camargo, and A. Portella. 2006. Occurrence of white-winged vampire bat, Diaemus youngi (Mammalia, Chiroptera), in the Cerrado of Distrito Federal, Brazil. Revista Brasileira de Zoologia 23:893-896.

Altringham, J. D. 1996. Bats: Biology and behavior. Oxford University Press. New York, U. S. A.

ANDERSON, R., AND H. Filmo. 2006. Dípteros ectoparasitas (Diptera, Streblidae) de filostomídeos (Chiroptera, Mammalia) do parque municipal no cinturão verde de cianorte, Paraná, Brasil e sua incidênciaao longo das estações do ano. Chiroptera Neotropical 12:238-243.

Azevedo, A., and P. Linardi. 2002. Streblidae (Diptera) of phyllostomid bats from Minas Gerais, Brazil. Memórias do Instituto Oswaldo Cruz 97:421-422.

BAllesteros, J., C. FeRnÁNDEZ, AND R. DueÑAs. 2006. Introducción a la diversidad faunística del Departamento de Córdoba. Informe técnico. Universidad de Córdoba, Facultad de Ciencias Básicas e Ingenierías. Montería, Colombia.

Ballesteros-Correa, J. 2015. Efecto del manejo silvopastoril y convencional de ganadería extensiva sobre el ensamblaje de murciélagos asociados a fragmentos de bosque seco tropical en Córdoba, Colombia. Tesis doctoral. Doctorado en Ciencias Biológicas. Facultad de Ciencias. Pontificia Universidad Javeriana. Bogotá, Colombia.

Bergallo, H., C. Esbérard, M. Ribeiro, V. Lins, R. Mangolin, G. Melo, and M. BAPTISTA. 2003. Bat species richness in Atlantic Forest: What is the minimum sampling effort? Biotropica 35:278-288.

Berlota, P., C. Aires, S. Favorito, G. Graciolli, M. Amaku, and R. PintoDA-Rocha, R. 2005. Bat flies (Diptera: Streblidae, Nycteribiidae) 
parasitic on bats (Mammalia: Chiroptera) at Parque Estadual da Cantareira, São Paulo, Brazil: parasitism rates and hostparasite associations. Memórias do Instituto Oswaldo Cruz 100:25-32.

Boshell, J., AND J. KerR. 1942. Veinticinco especies nuevas de Trombidiideos de Colombia. Revista Academia Colombiana de Ciencias 5:110-127.

Bush, A. O., K. D. Lafferty, J. M. Lotz, and A. W. Shostak. 1997. Parasitology meets ecology on its own terms: Margolis et al. revisited. Journal of Parasitology 83:575-583.

Calonge-Camargo, B. 2012. Ectoparásitos de murciélagos presentes en fragmentos de bosque seco tropical en manejos de ganadería convencional y silvopastoril (Córdoba - Colombia). Tesis de Maestría. Maestría en Ciencias Biológicas. Facultad de Ciencias. Pontificia Universidad Javeriana. Bogotá, Colombia.

Camilotti, V. L., G. Graciolli, M. M. Weber, J. Arruda, and N. Cáceres. 2010. Bat flies from the deciduous Atlantic Forest in southern Brazil: Host-parasite relationships and parasitism rates. Acta Parasitologica 55:194-200.

Christe, P., M. Giorgl, P. Vogel, and R. Arlettaz. 2003. Differential species-specific ectoparasitic mite intensities in two intimately coexisting sibling bat species: resource-mediated host attractiveness or parasite specialization? Journal of Animal Ecology 72:866-872.

CLARK, G. M. 1967. New Speleognathinae from Central and South American mammals (Acarina, Trombidiformes). The Helminthological Society of Washington 32:240-243.

Cloutier, D., AND D. Thomas. 1992. Carollia perspicillata. Mammalian Species 417:1-9.

Dick, C. W., M. R. Gannon, W. E. Little, and M. J. Patrick. 2003. Ectoparasite associations of bats from central Pennsylvania. Journal of Medical Entomology 40:813-819.

Dick, C. W., AND D. Gettinger. 2005. A faunal survey of streblid flies (Diptera: Streblidae) associated with bats in Paraguay. Journal of Parasitology 91:1015-1024.

Dick, C. W., Graciollı, G., ANd R. Guerrero. 2016. Family Streblidae. Zootaxa 4122:784-802.

Durán, A., Álvarez-Garcia, D., and G. Graciolli. 2017. Ectoparasitic flies (Diptera, Streblidae) on bats (Mammalia, Chiroptera) in a dry tropical forest in the northern Colombia. Papéis Avulsos de Zoologia 57:105-111.

EMERSON, J., AND A. RoARK. 2007. Composition of guano produced by frugivorous, sanguinovorous, and insectivorous bats. Acta chiropterologica 9:261-267.

Emmons, L., AND F. FeER. 1997. Neotropical rainforest mammals: a field guide. University of Chicago Press. Illinois, U. S. A.

Esberard, C. E. L., A. C. Jesus, A. Motta, H. Bergallo, and D. Gettinger. 2005. Hesperoctenes fumarius (Hemiptera: Polyctenidae) Infesting Molossus rufus (Chiroptera: Molossidae) in Southeastern Brazil. The Journal of Parasitology 91:465-467.

Fernández, A., R. Guerrero, R. Lord, J. OchoA, and G. Ulloa. 1988. Mamíferos de Venezuela: Lista y claves para su identificación. 1 ra. Edición. ASOVEM. Caracas, Venezuela.

FRITZ, G. 1983. Biology and ecology of bat flies (Diptera: Streblidae) on bats in the genus Carollia. Journal of Medical Entomology 20:1-10.

Gardner, A. L. 2007. Order Chiroptera. Pp. 187-188 in Mammals of South America: Volume 1 Marsupials, Xenarthrans, Shrews, and Bats (Gardner, A. L., ed.). Chicago: University of Chicago Press. Chicago, U. S. A.

Graciolli, G., and C. J. B. Carvalho. 2001. Moscas ectoparasitas (Diptera, Hippoboscoidea) de morcegos (Mammalia, Chiroptera) do Estado do Paraná. 11. Streblidae. Chave pictórica para gêneros e espécies. Revista Brasileira de Zoologia 18:907-960.

Graciolli, G., F. Passos, W. Pedro, and B. Lim. 2006. Moscas ectoparasitas (Diptera, Streblidae) de morcegos filostomideos (Mammalia, Chiroptera) na Estação Ecológica dos Caetetus, São Paulo, Brasil. Revista Brasileira de Zoologia 23:298-299.

Guerrero, R. 1993. Catálogo de los Streblidae (Diptera: Pupipara) parásitos de murciélagos (Mammalia: Chiroptera) del nuevo mundo. I. Clave para los géneros y Nycterophiliinae. Acta Biológica Venezuelica 14:61-75.

Guerrero, R. 1997. Catálogo de los Streblidae (Diptera: Pupipara) parásitos de murciélagos del nuevo mundo. VII. Lista de Especies, hospedadores y países. Acta Biológica Venezuelica 17:9-24.

HART, B. L. 1990. Behavioral adaptations to pathogens and parasites. Neuroscience and Biobehavioral Reviews 14:273-294.

Herrera-Sepúlveda, M.T. 2013. Comparación de la carga de ectoparásitos entre harenes y grupos mixtos de la población de Carollia perspicillata en la cueva Macaregua (Santander, Colombia). Tesis de Pregrado. Biología. Facultad de Ciencias. Pontificia Universidad Javeriana. Bogotá, Colombia.

Kerth, G. 2008. Causes and consequences of sociality in bats. BioScience. 58:737-746.

Komeno, C., AND A. Linhares. 1999. Batflies parasitic on some phyllostomid bats in southeastern Brazil: Parasitism rates and host-parasite relationships. Memórias do Instituto Oswaldo Cruz 94:151-156.

Kunz, T. H. 1976. Observations on the winter ecology of the bat fly Trichobius corynorhini. Journal of Medical Entomology 12:631-636.

Laval, R. K., And B. Rodríguez-H. 2002. Murciélagos de Costa Rica, Bats. 1 ed. Instituto Nacional de Biodiversidad, INBio, Santo Domingo de Heredia, Costa Rica.

LinARES, O. 1998. Mamíferos de Venezuela. Primera edición. Sociedad Conservacionista Audubon de Venezuela. Caracas, Venezuela.

Machado-Allison, C., and R. Antequera. 1969. Algunos datos sobre la distribución y huéspedes de los Spinturnicidae de Colombia (Acarina, Mesostigmata, Spinturnicidae). Caldasia 10:371-376.

Marinkelle, J. 1967. Cimex hemipterus from bats in Colombia, South America. Proceedings of the Entomological Society of Washington 69:179-180.

Marinkelle, J., and E. Grose. 1981. A list of ectoparasites of colombian bats. Revista de Biología Tropical 29:11-20.

Marshall, A. G. 1991. The ecology of ectoparasitic insects. Academic Press. New York, U. S. A.

Marshall, A. 1982. Ecology of insects ectoparasitic on bats. Pp. 369-401, in Ecology of bats (Kunz, T., ed. ). Plenum Press. New York. U. S. A.

McCracken, G., and G. Wilkinson. 2000. Bat mating systems. Reproductive biology of bats. Academic Press. New York, U. S. A. 
Moore, S. L., AND K. WILSON. 2002. Parasites as a viability cost of sexual selection in natural populations of mammals. Science 297:2015-2018.

Mooring, M., D. Reisig, J. Niemeyer, and E. Osborne. 2002. Sexually and developmentally dimorphic grooming: A comparative survey of the Ungulata. Ethology 108:911-934.

Morand, S., J. Gouy de BellocQ, M. Stanko, y D. Miklisová. 2004. Is sexbiased ectoparasitism related to sexual size dimorphism in small mammals of central Europe? Parasitology 129:505-510.

OchOA, J. 1985. El murciélago carnívoro Chrotopterus auritus (Peters). Natura 77:30-32.

Patterson, B. D., C. W. Dick, And K. Dittmar. 2007. Roosting habits of bats affect their parasitism by bat flies (Diptera:Streblidae). Journal of Tropical Ecology 23:177-189.

Presley, S. J., AND M. R. Willig. 2008. Intraspecific patterns of ectoparasite abundances on Paraguayan bats: effects of host sexa nd body size. Journal of Tropical Ecology 24:75-83.

Racero-Casarrubia, J., J. Ballesteros-Correa, and J. Pérez-Torres. 2015. Mamíferos del departamento de Córdoba-Colombia: Historia y estado de conservación. Biota Colombiana 16:128-148.

Racero-Casarrubia, J., J. Pinedo-Hernandez, J. Ballesteros-Correa, and J. Marrugo-Negrete. 2017. Metales pesados en especies de murciélagos (Quiróptera) asociados a una finca bajo manejo silvopastoril en el departamento de Córdoba, Colombia. Acta Zoológica Mexicana (n. s.) 33:45-54.

RuI,A. M., AND G.GraciolLI. 2005:Moscas ectoparasitas(Diptera, Streblidae) de morcegos (Chiroptera, Phyllostomidae) no sul do Brasil: associações hospedeiros-parasitas e taxas de infestação. Revista Brasileira de Zoologia 22:438-445.

Rrckman, R. E., AND M. A. CASDIN. 1977. The Polyctenidae of the world, A checklist with Bibliography. Vector Views 24:25-31.

Santos, M. F., L. Aguirre, B. Vázquez, and J. Ortega. 2004. Phyllostomus hastatus. Mammalian Species 722:1-6.

Santos, C. L. C., A. C. N. Pereira, V. J. C. Bastos, G. Graciolli, and J. M. M. Rebêto. 2013. Parasitism of ectoparasitic flies on bats in the northern Brazilian cerrado. Acta Parasitologica 58:207-214.

SCHUH, R. T., AND J. A. Slater. 1995. The true bugs of the world (Hemiptera: Heteroptera). Classification and Natural History Cornell University Press, Ithaca. New York, U. S. A.

SIKES, R. 2016. 2016 Guidelines of the American Society of Mammalogists for the use of wild mammals in research and education. Journal of Mammalogy 97:663-688.

Tarquino-Carbonell, A., K. Gutiérrez-Díaz, E. Galindo-Espinosa, G. Reinoso-Flórez, S. Solari, S. and R. Guerrero. 2015. Ectoparasites associated with bats in northeastern Tolima, Colombia. Mastozoología Neotropical 22:349-358.

TAsmitT, J. R., AND I. Fox. 1970. Records of bat ectoparasites from the Caribbean region (Siphonaptera, Acarina, Diptera). Canadian Journal of Zoology 48:1093-1097.

ter Hofstede, H., AND M. B. Fenton. 2005. Relationships between roost preferences, ectoparasite density, and grooming behaviour of neotropical bats. Journal of Zoology 266:333-340.

ter Hofstede H.M., M.B. Fenton, And J.O. Whitaker JR. 2004. Host and host-site specificity of bat flies (Diptera: Streblidae and Nycteribiidae) on Neotropical bats (Chiroptera). Canadian Journal of Zoology 82:616-626.

TheODOR, O. 1967. An illustrated catalogue of the Rothschild collection of Nycteribiidae (Diptera) in the British Museum
(Natural History). British Museum of Natural History. London, England.

TIMm, R.M., AND R.K. LAVAL. 1998. A field key to the bats of Costa Rica. Ocassional publication series, University of Kansas, Center of Latin American Studies 22:1-30.

TUtTLE, M. D. 1970. Distribution and zoogeography of Peruvian bats, with comments on natural history. University of Kansas. Science Bulletin 49:45-86.

Ueshima, N. 1972. New World Polyctenidae (Hemiptera), with special reference to Venezuelan species. Brigham Young University Science Bulletin 17:13-21.

WenzeL, R.L. 1976. The streblid batflies of Venezuela (Diptera: Streblidae). Brigham Young University Science Bulletin 20:177. Wenzel, R., J. TIPTON, AND A. KIEWLICZ. 1966. The streblid batflies of Panama (Diptera: Streblidae). Pp: 405-675, in Ectoparasites of Panama (Wenzel, L., and V. Tipton, eds.). Field Museum of Natural History. Chicago.

WhitAKER, J., C. RITZI, AND C. DiCK. 2009. Collecting and preserving bats ectoparasites. Pp. 806 - 827, in Ecological and Behavioral Methods for the Study of Bats (Kunz, T., and S. Parson, eds.). Second edition.

Zhang, L., S. Parsons, P. Daszak, L. Wel, G. Zhu, and S. Zhang. 2010. Variation in the abundance of ectoparasitic mites of flatheaded bats. Journal of Mammalogy 91:136-143.

Associated editor: Rafael Ávila

Submitted: April 1, 2017; Reviewed: June 17, 2017;

Accepted:May 15, 2018; Published on line:May 30, 2018. 